\title{
The Revelatory Text and the prologue of the Gospel of Luke
}

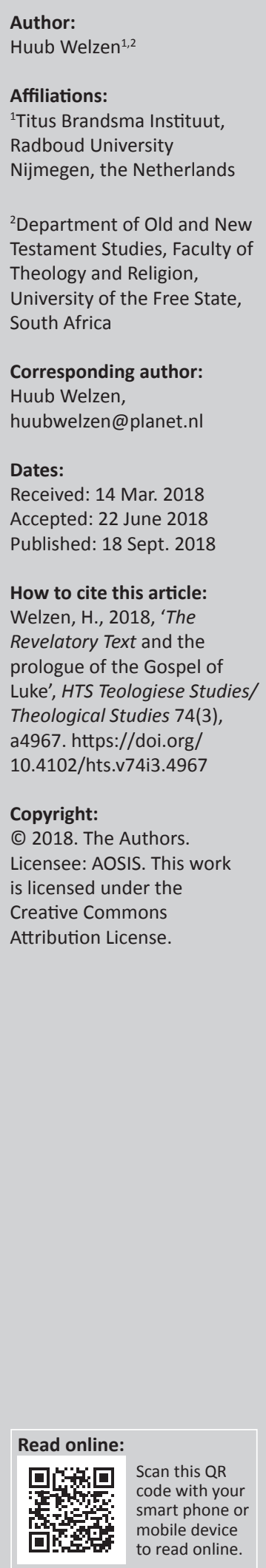

The first print of the book of Sandra Schneiders, The Revelatory Text, appeared more than 25 years ago. With the help of the hermeneutic theories of Gadamer and Ricoeur, she proposes a kind of exegesis that integrates scholarly methods and spiritual reading. In this article we investigate how the model of Sandra Schneiders is congruent with the old intuition of the lectio divina. We compare the model of Schneiders with the systematisation of the lectio divina by Guigo II, the Carthusian. As a result, we see in the text of Guigo the pre-understanding of the Carthusian spiritual life at work. And as a result we also recognise Schneiders' transformative understanding of the subject matter of the text in the phase of the oratio and the comtemplatio. In the model of Guigo, there is also room for critical analysis in the phase of the meditation. We investigate also if the Bible itself gives indications for the kind of exegesis Schneiders proposes. What Schneiders says about pre-understanding is present in the prologue of the Gospel of Luke. Luke considers the story he tells as a history guided by God. What Luke tells about the genesis of his text belongs to the world behind the text. The world of the text is present as a well-ordered world. Luke speaks also about the transformation of the reader. In this, we recognise what Schneiders says about the world before the text and the transformative understanding of the subject matter of the text. We conclude that the model of Schneiders is innovative in relation of common academic exegesis. It is rooted in the tradition of Christian spiritual reading, and it is present in those biblical texts which indicate how to read.

\section{Introduction}

The book of Sandra Schneiders, The Revelatory Text ${ }^{1}$, is rooted in an awareness that the historical critical approaches of the Bible do not answer some important questions (Schneiders 1999:1-7). ${ }^{2}$ This awareness grew slowly. The questions are related to two fields. The first concerns the preunderstanding. It is about questions which relate the inspiration of the Bible, the Bible as the word of God and the Bible as the book of the Church. Does a religious pre-understanding have consequences for the meaning of the text? The second question relates the relation of the text and the reader. Currently, hermeneutic models illustrate that the presupposition of the historical critical methods that the meaning of a text can be established objectively is untenable. Meaning is not a separated phenomenon existing apart from the interpreting subject. On the contrary, meaning is an event happening again and again in the interaction of text and reader.

In this article, we investigate how the proposals of Schneiders are congruent with the Christian tradition of lectio divina and how her ideas are already present in some Biblical texts. In this way, we want to show the importance of The Revelatory Text for the academic disciple of Biblical spirituality. We do this in three steps. In the first step, we will show the innovative character of The Revelatory Text. The second step is a comparison with the age-old tradition of spiritual reading known as lectio divina. More precisely, we make a comparison with the systematised presentation of this way of reading by Guigo II, the Carthusian, and the integration of this system in the model of Waaijman (2002:689-773). As a third step, we will show how a hermeneutic model as the model of Sandra Schneiders is already present in the prologue of the Gospel of Luke.

\footnotetext{
1.Biblical spirituality gets more and more attention in the academic world of biblical scholarship. An important contribution is supplied by the new hermeneutic insights which pay attention to the role of the reader in the process of attributing meaning to a text. This new attention owes very much to the efforts of scholars who underline the importance of spirituality in the study of the Bible again and again. In South Africa, Pieter de Villiers and Celia Kourie did magnificent work in this respect. I enjoy a contact of many years standing with them, which inspires and challenges me. In my contribution to this collection in honour of them, I start with the book of Sandra Schneiders, The Revelatory Text, whose first print appeared more than 25 years ago. In my view, it is still an important book that wants to integrate scholarly exegesis and Christian spirituality. This book has played an important role in the development of biblical spirituality in South Africa.
}

Note: Prof. Welzen is a research fellow of Prof. P.G.R. de Villiers, Extraordinary professor, Old and New Testament Studies, Faculty of Theology and Religion, University of The Free State, South Africa. 


\section{The innovative character of The Revelatory Text}

The Revelatory Text is addressed to a specific audience:

intelligent and educated believers who wonder how sound biblical criticism can be incorporated into a faith-filled and faithenhancing reading of the New Testament; believing biblical scholars who struggle with the question whether or how faith can function legitimately in biblical scholarship; and those whose task it is to teach and preach the faith that looks to the New Testament, properly and integrally understood as source and norm. (Scheiders 1999:13)

This audience determines also the aim of the book. The purpose:

is elaborate a theory of New Testament interpretation that can ground a reading of the New Testament that is unreservedly critical, on the one hand, and that interacts meaningfully with the personal and communal spiritual life of the believer, whether scholar or lay, on the other. (Schneiders 1999:13)

This aim implies enormous shifts regarding the scholarly ideal that characterised the historical critical approaches and also the text-oriented structuralist approaches. The historical critical methods are based on a 19th century, objectivistic, scientific ideal in which the researching subject had to distance from the researched object as much as possible. The results of this kind of research had to be objective, verifiable and valid forever. The historic critical approaches are directed especially to questions about the conformity of the texts and the events in history to which the text refers, to the genesis of the texts and to the intention of the author. Also, the structuralist and semiotic approaches claim that these analyses lead to an objective meaning by determining the depth structure of a text.

The actual results of the historical critical methods diverge from the intention of these methods. Academic libraries are jungles of theories and hypotheses. These results make us doubt about the presupposition of objectivity. But also from the viewpoint of epistemology, it is impossible to research objects which have to do with reality in an objective manner, for the researcher participates in the reality which the object refers to. In this way, the researcher participates in the object he looks into. The same objection can be made against the pretention of objectivity of structuralist approaches. This type of research is turned to structures of values which underlie the text to be researched. These values are organised in semiotic patterns of contrary relations, relations of contradictions and relations of implications. In these patterns of underlying values, the researcher participates too.

Sandra Schneiders wants to overcome the idea of objectivity by drawing in the relation of text and reader in the research. She therefore uses the hermeneutical ideas of Gadamer and Ricoeur. The idea of Gadamer, rooted in a long hermeneutical tradition, that the meaning of a text comes into being in a dialogue with the text, is decisive. Instead of the idea of objective research and meaning stated objectively, there is a different critical idea: the idea of intersubjectivity. '[T]he known ... is always known in and through the experienced historical consciousness of the knower and in relation to everything else that is known, never "in itself"' (Schneiders 1999:161). The explanation of the New Testament is solved from an overtaken 19th century idea of science and brought to a model that is more fitting for current disciplines of interpretation. The consequences bound by Ricoeur to the fact that the text has taken leave of its author, the original context and the original addressees disagree with the idea of an eternally valid meaning of the text. The text has become semantically autonomous (Schneiders 1999:123) and is read in ever-changing contexts. Because of this, new meanings come into being again and again. Meaning is not an objective fact anymore. Meanings are events, happening again and again, every time the text is read. The text has the competence for generating new meanings in contact with new readers.

However, Sandra Schneiders did not reject the historical critical and structuralist approaches in spite of her criticism of their objectivistic character. She gives them their place in her hermeneutic model that consists of three parts: the world behind the text, the world of the text and the world before the text. For the analysis of the world behind the text, we may use historical, literary, psychological, sociological, ideology critical, theological, religious and spiritual approaches (Schneiders 1999:97-131). In the chapter speaking about the world of the text, the historicity and the reliability of the literary testimony are discussed. Literary approaches have here their home, just as sociological, psychological, rhetorical and ideology critical approaches directed to the role of the reader. Sandra Schneiders reckons these approaches to the methods which explore the world of the text (Schneiders 1999:132-156). Important are the semantic autonomy of the written text and the surplus of its meaning. These elements give the text the competence to have several meanings in several contexts (Schneiders 1999:142-144).

The third part is that of the word before the text (Schneiders 1999:157-179). In this chapter, Sandra Schneiders reaches the proper aim of her book. She uses here the term 'transformative understanding of the subject matter of the text' (Schneiders 1999:169). In my view, this is the most important term of her book. The term refers to Chapter 1 where Schneiders explains that there are two points of view from which the New Testament can be read and studied. The text can be read for information or in view of transformation (Schneiders 1999:13-14). Because the New Testament is a historical document, the text contains all kinds of information about the time of its origin, about ideas in that time, about the culture of that time, about events the text refers to and so on. By doing research and critical reading, we can try to understand this information. But if we read the text with the aim of transformation, this is an existential project that belongs to the field of spirituality. The reader aims to be involved in the truth the text is speaking about. These two perspectives are related to each other, but they are not identical. One can study the New Testament in view to get 
information and exclude the transformational aspect. The reversed way is impossible. Reading from the transformational point of view, the reader has to deal with the aspects of information (Schneiders 1999:14).

The hermeneutical models of Gadamer and Ricoeur offer Sandra Schneiders the possibilities to discuss the existential relation of the reader and the researcher to the text. Gadamer uses terms such as application and fusion of horizons. These terms refer to the process through which the world of the text and the world of the reader touch each other, influence each other and even melt with each other. Apart from that, Schneiders thinks that application is an unfortunate term in some ways (Schneiders 1999:160). Ricoeur uses the term appropriation. With this term, he indicates the transition from the first naïveté, via a critical phase, to the second naïveté (Schneiders 1999:169). The first naïveté is the spontaneous and uncritical understanding of the text. In the critical phase, there is more distance to the text. The text is examined in many ways. At that moment, the text has become more transparent by intensive requirement, and a transformative meeting of the reader or researcher and the subject matter of the text could happen. The reader is gripped by this subject matter and he enjoys the text. Sandra Schneiders (1999) wonders if people who don't know these moments when the contact with the text creates new worlds will come to a full understanding of the text:

I would question whether someone who has never felt the religious power of the gospel text, no matter how learned her or his biblical scholarship might be and regardless of whether she or he actually comes to share Christian faith, is competent for New Testament research. (p. 173)

Sandra Schneiders calls this experience of existential understanding, where of the subject matter and the world of the reader touch each other and influence each other, the transformative understanding of the subject matter of the text (Schneiders 1999:169-178).

The subtitle of the book makes clear that Sandra Schneiders approaches the New Testament in a specific way. The subtitle is Interpreting the New Testament as Sacred Scripture. A specific pre-understanding of the New Testament becomes visible: the New Testament as Sacred Scripture. In the definition of the object, the religious and spiritual pre-understanding of the researcher is integrated. This pre-understanding makes it possible that the interpretation process reaches its final goal: the transformative understanding of the subject matter of the text. In the first part of the book, this pre-understanding is elaborated in the chapters about the New Testament as the word of God (Schneiders 1999:27-63) and the New Testament as book of the Church (Schneiders 1999:64-93). The integration of critical methods in reading and research preserves the interpretation process for a fundamentalist attitude. 'Fundamentalism, fanaticism, and socially disfunctional literalism are vivid examples of biblical "spirituality" that bypasses critical scholarship' (Schneiders 2002:142). At the same time, it becomes clear that because of this pre-understanding the reader and researcher are not out of range. Their pre-understanding is determined partly by their social and communal position. It is this pre-understanding that makes anonymous and objective results of the research impossible. In her book, Sandra Schneiders (1999) puts into words her relation to the text of the New Testament:

as a white, middle class, First World, European educated, feminist member of a Roman Catholic women's religious congregation who is both a professional in the fields of biblical studies, theology, and spirituality and a committed believer. (p. 4)

Her book is dictated by her 'particular, indeed passionate interest in the possibility of the Bible's, especially the New Testament's, functioning as locus and mediation of revelatory encounter with God, that is as revelatory text for its readers' (Schneiders 1999:4). By putting into words this preunderstanding, it becomes clear from which point of view Sandra Schneiders approaches the text. She does not suppress her pre-understanding as usual in many academic exegetical studies which create a semblance of objectivity. By putting into words the pre-understanding, it becomes part of the discussion. In this way, her understanding of the text meets the hermeneutical condition of critical intersubjectivity. This idea is a reciprocal idea. There is a critical attitude of the reader and the researcher towards the text, and at the same time the texts influence the pre-understanding of the reader and the researcher. The subject matter of the text confronts the reader with otherness. In the case of religious and biblical texts, this is even a transcendental otherness.

The innovative character in the book of Sandra Schneiders is that the existential and transforming perspectives are integrated in an academic context. Herewith important shifts appear in comparison with the objectivistic scholarly model on which historical critical exegesis was based. We sum up some of these shifts:

- The idea of meaning stated objectively has become untenable.

- The reading and researching subject participates in the process of interpretation.

- The subject-object relation in the research has been changed into a relation of intersubjectivity.

- Meaning has no universal validity, but happens as an event every time the text is read.

- The pre-understanding is steering for the way meaning comes into being.

- Meaning in the sense of transformative understanding of the subject matter of the text has an impact on the reader.

The project of Sandra Schneiders is innovative. When reading Scripture, she tries to integrate the dimension of spirituality in academic exegesis. This implies that biblical spirituality, not only in the sense of the research of the spirituality of the texts themselves but also in the sense of the impact of the biblical texts in the readers, ${ }^{3}$ has its own place in the university

3.In her article about Biblical Spirituality of 2002 , Schneiders circumscribes biblical spirituality in a threefold way: (1) biblical spirituality refers to the spiritualities that spirituality in a threefold way. (1) biblical spirituality refers to the spiritualities that come to expression in the Bible; (2) biblical spirituality designates a pattern of Christian ife deeply imbued with the spirituality(les) of the Bible; (3) a third meaning of the term biblical spirituality is the transformational process of persona and communal engagement with the biblical text (Schneiders 2002:134-136). In her article of 2016 with the same title, Schneiders circumscribes biblical 
as a full-grown academic discipline. The success of her project depends on the extent to which researchers accept current insights into the relation of text and reader when studying biblical texts. Authors such as Eco $(1983 ; 1989)$ and Iser $(1976$; 1979) offer important insights in this regard, which are very helpful for the success of the project of biblical spirituality.

\section{Based on old intuitions}

The hermeneutic model of Sandra Schneiders is innovative in relation to the current academic exegesis. But in fact, it is about very old intuitions. For centuries, exegesis and spirituality were related to each other very closely. Explanation of biblical texts was at the service of spiritual life, and the questions of spiritual life directed the research of the Bible. Of course, the exegesis in Antiquity and the Middle Ages did not meet the criteria of current academic exegesis. But, the study of important hermeneutical works of Origines, Augustine and others makes clear that their exegesis was for sure not without criteria. They knew a critical attitude towards the texts. ${ }^{4}$ In the 12th century, Guigo II, the Carthusian, has described and systematised the current practice of lectio divina in his writing, Scala Claustralium (Guigo II 1970). He describes four steps: lectio, meditatio, oratio and contemplatio. Guigo gives several circumscriptions of these four steps. The analysis of these circumscriptions leads me to the following conclusions:

$[H]$ uman effort is involved in the phases of the lectio and the meditatio to understand the text and its meaning. The meditatio is a continuation of the process that started with the lectio. The meditatio uses the intellectual abilities. It is focused on further delving into the secrets of the text. Of particular importance is the way in which Guigo speaks about the orative and the contemplative phases of the reading process. In these phases of the reading process, commitment to God comes into play. Compared with meditatio, oratio entails a major transition. The focal issue is not extracting the meaning of the text, but relating to its contents. Guigo characterises this relationship as longing when he describes the basic movement of prayerful reading as desiderium. This longing is grounded in meditation. Prayer is kindled by meditation. The longing is explicitly directed to God. (Welzen 2017:52)

[T] he system does make it clear that the process is not focused on meaning, but on involvement. This becomes particularly clear where Guigo speaks about prayer as longing: i.e. the outstretched movement of the praying reader to the Secret referred to in the text. On the other hand, the contemplative phase speaks about the conciliatory movement of God, who comes to meet the longing person in the longing person's prayer. These two movements - in the oratio from the man towards God, and in the contemplatio from God towards man - are the main movements in the relationship between God and man. (Welzen 2017:53-54)

In the third part of his book about spirituality, Waaijman speaks about the academic study of spirituality. One of the

(footnote 3 continues...)

spirituality again in a threefold way. This circumscription differs from the article of 2002. Biblical spirituality is (1) the lived faith experience that gave rise to the biblical text; (2) the spirituality expressed in the biblical text; and (3) the spirituality to text; (2) the spirituality expressed in the biblical text; and (3) the spirituality
which the Bible gives rise throughout Christian history (Schneiders 2016:418).

4.In my book, Biblical Spirituality, I give summaries of the works of Origines, Didyme the Blind, John Cassian, Augustine, Guigo II the Carthusian and the New Devotion (Welzen 2017:27-66). approaches is the hermeneutic study. The model of Guigo is one of the building stones for the hermeneutic model Waaijman presents in his book (Waaijman 2002:689-773). His design consists of six steps: the pre-understanding, the act of reading, critical analysis, theological pragmatics, the revelation of the mystery and the ongoing impact. As far as I can see the models of Sandra Schneiders and Kees Waaijman came into being independent from each other. In a first view, they don't resemble each other. But in the second view, it appears that there are important and profound conformities. The question can even be asked if the two models don't have one and the same purpose: the transformation of the reader which is elaborated by the relation of the reader to the subject matter of the text. I like to show this in relation to the preunderstanding, the place of the critical methods and the transforming character of the reading process.

Kees Waaijman pays much attention to the pre-understanding (Waaijman 2002:729-741), the way the text appears to its reader and the way the reader approaches the text interlock. For me, it is clear that a thumb-marked edition of NestleAland $^{28}$ or $\mathrm{UBS}^{5}$ at the desk of a biblical scholar in the midst of commentaries and at the screen of the computer Bibleworks ${ }^{10}$ expresses a pre-understanding different from the beautiful and rich decorated lectern bible with gild edges and bound in calf. In the text of Scala Claustralium, Guigo does not discuss explicitly the pre-understanding. But this does not mean that the pre-understanding is absent. There are several matters indicating a pre-understanding situated in a monastic context where the Bible was read in view of spiritual life.

A first point is the title of this writing. Scala Claustralium means 'ladder of monks'. ${ }^{5}$ This title indicates that this writing wants to be a guide for the spiritual life as lived in a Carthusian monastery. The text itself indicates this spiritual way where it speaks about the four rungs of the ladder:

These make a ladder for monks by which they are lifted up from earth to heaven. It has few rungs, yet its length is immense and wonderful, for its lower end rests upon the earth, but its top pierces the clouds and touches heavenly secrets. (Guigo II 1981:67-68)

The text is an allusion to Jacob's dream in Genesis 18:12. This dream is interpreted as being related to the way in which people can rise to the heavenly secrets in spiritual life. This pre-understanding implies that the biblical text brings the reader in contact with the subject matter of the text. We may recognise here the transformative impact Sandra Schneiders describes speaking about the transformative understanding of the subject matter of the text.

A second point that makes visible the pre-understanding in the Scala Claustralium is the literary form of the text. The text is a letter of Guigo to his brother Gervasius. He submits some thoughts which came up when he was thinking about the religious life of the monks. Guigo asks Gervasius to review [a letter about contemplative life] and Scala Paradisi [ladder of the paradise]. 
and to correct these thoughts (Guigo II 1981:67). Herewith Guigo puts himself under the direction of a person with experience in spiritual life. ${ }^{6}$ Here also the relation with the life of the Carthusians and the spiritual way becomes visible.

The third point is the way Guigo (II 1981) introduces the corpus of his writing:

One day when I was busy working with my hands, I began to think about our spiritual work, and all at once four stages in spiritual exercise came into my mind: reading (lectio), meditation (meditatio), prayer (oratio) and contemplation (contemplatio). (pp. 67-68)

The insight in the four rungs of spiritual life arises while keeping the monastic order of the day. The words 'working with my hands' indicate this. During the manual labour, spiritual texts are meditated (I began to think about our spiritual work). Because of the allusion to Jacob's dream in Genesis 28:12, we may even say that the world of the biblical text and the world of the Carthusian life touch each other. In that case, the text of Guigo is an example of what Sandra Schneiders has called the transformative understanding of the subject matter of the text.

We want to speak not only about the pre-understanding but also about the place of the critical methods in the system of Guigo. We look for this place especially in the phase of the meditation. The lectio is about the careful reading in which the obvious meaning of the text originates. In Antiquity and the Middle Ages, the meditatio consists of the rumination of the text that was read. The text was recaptured piece by piece and ruminated till the text gave up its secrets. Guigo writes about meditation in such a way that it becomes clear that this is analytical work with the help of the reason. 'Meditation is the busy application of the mind to seek with the help of one's own reason for knowledge of hidden truth' (Guigo II 1981:67-68). 'Meditation considers more carefully what is to be sought after it; it digs, as it were, for treasure which it finds and reveals ...' (Guigo II 1981:79-80). 'Meditation is concerned with the inward understanding' (Guigo II 1981: 79-80). In his model of spiritual hermeneutics, Kees Waaijman places here six critical analytical approaches: the analysis of the part-whole relation (composition); the depth-structure; the intertextual relations; the contextual reconstructions; the pragmatics of the text; and the religious field of meaning (2002:748-755). ${ }^{7}$ We conclude that in the systematic presentation of the lectio divina, there is room for the integration of critical analytical approaches. Especially, the methods named by Sandra Schneiders in the chapters about the world behind the text and the world of the text have a good place in the meditative phase of the reading process.

In the chapter about the world before the text, Sandra Schneiders speaks about the transformative understanding of the subject matter of the text. In the text of Guigo, this is

6.Integral reading of the Scala Claustralium gives us the impression that the author is not looking for guidance, but wanting to give direction.

7.I have the impression that this not an exhaustive enumeration. It should rather be regarded as some examples of the many possible analysis models. very well recognisable in the phase of the oratio and the contemplatio. Kees Waaijman calls these phases theological pragmatics (Waaijman 2002:755-756) and the revelation of the mystery (Waaijman 2002:763). In the oratio, the human desire is directed towards God. Here, an important shift has taken place in comparison with the meditation. Not the content of the text is the central point, but the relation with the subject matter of the text. This relation is characterised by desire. The typical words used by Guigo are asking, desiring and longing (Guigo II 1981:79-80). He calls this phase oratio [prayer], because desire is the kernel of prayer.

In the phase of contemplation, God comes to meet the longing human being:

But the Lord, whose eyes are upon the just and whose ears can catch not only the words but the very meaning of their prayers, does not wait until the longing soul has said all its say, but breaks in upon the middle of its prayer, runs to meet it in all haste. (Guigo II 1981:73-74)

The text of Guigo clears up that the process, called by Ricoeur appropriation and by Gadamer fusion of horizons, consists of two movements meeting each other: the longing movement of the human being and the movement of God coming to meet the desire of the human being. ${ }^{8}$ Guigo speaks also about the transforming aspects of this reading experience. He does so with the help of the literary device of the antiphrasis. Antiphrasis is a stylistic device in which words are used in a different, often opposite sense to their usual meaning. The sighs and tears of the desire are transformed to consolation and joy in the contemplation (Guigo II 1981:74-75). We can place this mystical transformation in the world before the text, whereSandraSchneiders speaks about the transformative understanding of the subject matter of the text. Sandra Schneiders mentions this transformation as one moment. But Guigo differentiates this as two movements meeting each other, the movement of the desire of the human being and the movement of God towards the longing human being.

Kees Waaijman adds the phase of the ongoing impact to this all. The process of transformation has a lasting impact on the life of the reader. But in his writing, Guigo warns that it may happen that people are blocked from the four steps of the spiritual way. Especially, vanity blocks from contemplation.

We can formulate now as a conclusion of our second step that the hermeneutic model of Sandra Schneiders is congruent with the lectio divina that is practised from Antiquity till our days. We have compared the model of Sandra Schneiders with the oldest systematised model of the lectio divina. These models correspond with each other in important points. They are directed to the mutual integration of critical approaches of the text and spiritual reading; there is room for critical analysis, so that people can pass a fundamentalist reading; they are directed to the transformation by the subject matter of the text. Herewith we have established not only that the book of Sandra Schneiders is innovative in relation to a huge

$8 . F o r$ a comparison and integration of the models of Sandra Schneiders, Kees Waaijman and Manfred Oeming, see Welzen 2017:113-122. 
part of academic exegesis but also that her hermeneutics are congruent with the century-long tradition of the Christian spiritual reading.

\section{The prologue of the Gospel of Luke}

In the last chapter of her book, Sandra Schneiders shows her hermeneutical model at work. The chapter offers a case study: A feminist interpretation of John 4:1-41. Also, her book about the Gospel of John is an illustration and application of the hermeneutical ideas presented in The Revelatory Text (Schneiders 2003:15-22). In the third part of this article, we want to do more than just apply the model. We want to show that in the prologue of the Gospel of Luke the most important elements of the model of Sandra Schneiders are present and that her model is congruent with the way Luke wanted his text to be read. We discuss consecutively the preunderstanding, the world behind the text, the world of the text and the world before the text. But first we remark that of course Luke doesn't give a hermeneutical theory about biblical texts. What he does is steering the way the reader reads his text. In this steering, we recognise the central elements of the model of Sandra Schneiders.

We start with the pre-understanding. It is recognised generally that the prologue of the Gospel of Luke has the characteristics of the historiography of his days (Unnik 1973a; 1973b). Luke presents his writing as history. Cadbury (1922:490) has already indicated this. As an alternative, Alexander (1993) has proposed that the prologue has the characteristics of scientific works of technology, medical science and rhetoric. In a very conscientious investigation, Baum (2010) has shown that the thesis of Alexander is not tenable and that the prologue harmonises most with the conventions of historiography in Antiquity. Sometimes, the Gospel of Luke is seen as a biography. One may classify the Gospel of Luke in this way, but it does not fit the whole of Luke-Acts (Green 1997:5).

In one important aspect, historiography is distinct from fictional literature. In the case of fictional literature, the author and the readers do not participate in the reality the text refers to. But in historiography they do. The reality the text refers to belongs to the past of the author and the readers. The mere literary genre relates the reader to the subject matter of the text.

But the text of the prologue relates the reader to this subject matter too. In verse 1 is spoken about the events that have been fulfilled among us, and in verse 2 about the tradition the servants of the word have handed over to us. It is argued that the word $\eta \mu \mathrm{iv}$ in verse 1 refers to the contemporaries of Jesus and that in verse 2 this word refers to the contemporaries of the author (Marshall 1978:14). Other interpreters think that this distinction is of less importance and that the two meanings have to be taken together as one 'ecclesiastical we' (Dillon 1981). Whatever this may be, in this moment it is important for us that the author using this 'we' understands himself and his readers as participating in the reality the text refers to.
It is also indicated that Luke writes biblical history (Maddox 1982:16). The argument for this is the transition in style between Luke 1:4 and Luke 1:5. The prologue is written in cultured Attic Greek, while the subsequent text is written in the style of the Septuaginta (Kurz 1987:208-209). This biblical history is a history guided by God. One can conclude this

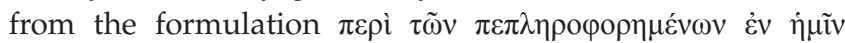
$\pi \rho \alpha \gamma \mu \alpha \dot{\tau} \omega \nu$ [the events that have been fulfilled among us]. The verbal form used here is a participle perfect passive. The perfect form indicates that an event in the past has its influence till now (Bruggen 1993:26). The passive form can be understood as a divine passive, meaning the events fulfilled by God (Dillon 1981).

The next point is that verse 2 is not a common relative sentence.

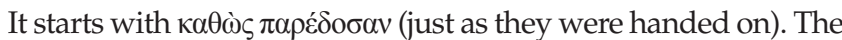
events the text of Luke refers to are traditions handed down to us. Luke places his story into a tradition that starts with the events seen by the eyewitnesses, then handed down by them as servants of the word, after that set down by the many as $\delta$ in $\gamma \eta \sigma \iota^{9}$ and eventually incorporated by Luke in his text.

The pre-understanding of Luke, looking to his work, becomes visible. His text refers to a history guided by God, participating in the biblical history. His text is part of a process of tradition which started with the eyewitnesses. Luke himself is for the time being an end of this process. The author and his readers participate in the history in which God has taken an initiative. In his survey of 55 years of research in Luke-Acts, François Bovon puts the question if Luke wants to narrate a holy history or an irruption of the word of God (Bovon 2006:83). In many places, Luke speaks in terms of intervention. But Bovon indicates how to interpret these texts. When Luke speaks in terms of intervention and miracles, these texts 'must be read in the perspective of the first century as signs of the active presence of the divine' (Bovon 2006:84):

Luke integrates without hesitation the fulfillment of the purpose of God ... into the live of humans. It is this junction, for lack of a better term, that we call salvation history. (Bovon 2006:84-85)

In the first part of her book, Sandra Schneiders discusses the implications of the pre-understanding of the New Testament from the viewpoint of two aspects: The New Testament as the word of God and the New Testament as book of the Church. Both aspects are recognisable in the Lucan project. In the story of Luke, Jesus is the main character. He preaches the

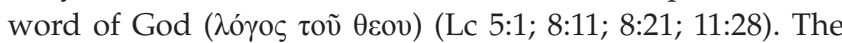
disciples of Jesus preach this word of God in Acts too (Ac $4: 31 ; 6: 2 ; 6: 7 ; 8: 14 ; 11: 1 ; 13: 7 ; 13: 46 ; 13: 48 ; 16: 32 ; 17: 13 ; 18: 11)$. In the prologue of Acts, Luke refers to the first part of his

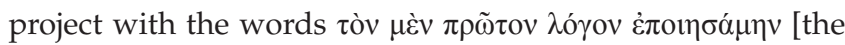
first word I have written]. The fact Luke uses the word $\lambda$ ó $\gamma$ here is an indication that he considers his work as the continuation of the preaching of the word of God.

In the prologue of the gospel, the word $\lambda$ óyos appears two times. The first time is in verse 2 , where is spoken about a

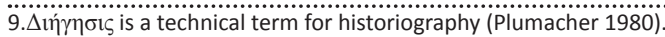


transformation of the eyewitnesses to servants of the word. Together with this transformation, the $\pi \rho \alpha \gamma \mu \alpha$ ó $\alpha$ [events] are transformed to $\lambda$ ó ${ }^{\circ} \varsigma$ [word]. In this double transformation, a tradition process starts in which the writings of Luke have their own place. The tradition becomes possible while the $\pi \rho \alpha \gamma \mu \alpha \dot{\alpha} \alpha \alpha$ have become $\lambda$ ó $\gamma$ os. The bearers of this tradition

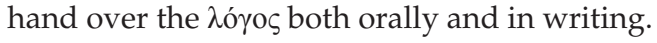

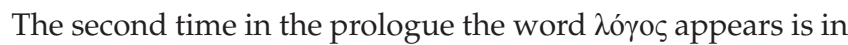
verse 4 . Luke mentions Theofilus is instructed 'about the words'. We will discuss the exact meaning of this verse later on. Now it is enough to see that there is a Christian tradition that is known to Theofilus. The word as part of the tradition and as indication of the first book of Luke means that there is a community in which this tradition is handed over, and which is formed by this tradition. We recognise the book of Luke as a book of this Christian community.

Now we can conclude that the aspects Sandra Schneiders discusses in the first part of her book in the chapters about the word of God and the book of the Church are also present in the prologue of the Gospel of Luke.

In the prologue of his gospel, Luke refers to the world behind the text in two ways. The first is that he mentions the events

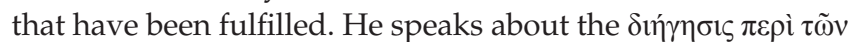

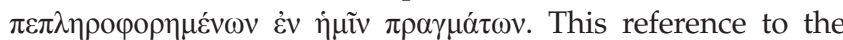
historical facts leads us to the distinctions Sandra Schneiders makes regarding the research of the historical Jesus (Schneiders 1999:100-102). She speaks about the actual Jesus, the historical Jesus and the proclaimed Jesus. In the prologue of the second edition, she discusses these terms again, and she adds a fourth term: the textual Jesus (Schneiders 1999:xxviii-xxx). The introduction of this terminology made me aware that the common use of the term 'the historical Jesus' has some dangers in it. The first danger is that the term suggests that we can reach the pure historical facts. It is important to realise that the sources we use in historical research are all interpretations of the facts. Sources are interpretations. Histories like the Gospel of Luke interpret historical facts by telling historical stories. 'Auch des in der historischen Erzählung entworfene Modell vergangenen Geschehens ist ein auf der Gerippe der Ereignisse basierendes, von Historiker gestaltetes und verantwortetes Sinngefüge' (Schröter 2007:29). If we try to reconstruct the historical reality from these interpretations, we do nothing else than interpret these interpretations. The result of historical research is interpretation of interpretations. A reconstruction of the pure historical facts is, seen from a hermeneutical point of view, an impossibility.

A second danger relates to the subject matter of the text. Sandra Schneiders (1999) makes clear that this subject matter is a mixed reality. It is about matters that are accessible for historical research and matters that are not:

For example: Jesus' birth is properly historical, but the incarnation is not; Jesus' death is historical, but the salvation of the world by his death is not; the Easter experiences of Jesus' disciples are historical but the resurrection is not. This does not mean that the incarnation, redemption and resurrection did not happen or are not real. It means that they are transhistorical; they belong to another sphere of reality that is not the subject matter of the human discipline of history. (p. 101)

Luke refers to the same mixed reality. We have shown this in the previous paragraph about the pre-understanding in the prologue. Luke tells about a history guided by God. That Gods acts in the human history is not accessible to historical research. Historical research does not consider God as an actor in history. This is not a negation of divine guidance in history. For this guidance is a religious and spiritual reality. Sandra Schneiders will call it 'transhistorical'.

Summarising we may say that what Sandra Schneiders is saying about the world behind the text is present in a recognisable way in the writings of Luke. His historiography is a writing referring to events in historical reality. But these events are not just historical. They have a revelatory character. Luke is aware of the genesis of his text too. He mentions the people who have written about the same subject-matter before him, and the oral and written traditions he used.

The world of the text is discussed in verse 3 of the prologue. In this verse, Luke mentions his own activities. He has made an investigation qualified by two adverbs. The word $\alpha$ v $v \theta \varepsilon v$ can mean 'from the beginning' and 'during a long time' (Marshall 1978:42). I prefer the meaning 'from the beginning'. It is supported by the way the first chapter of Acts speaks about the gospel and about capable candidates to fill up the number of the 12 apostles. In the prologue of Acts, Luke indicates that he wrote his first book about all that Jesus did and taught from

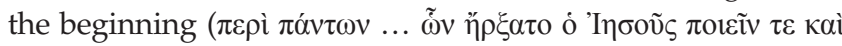
$\delta ı \delta \dot{\alpha} \sigma \kappa \varepsilon ı v)$ until the day when he was taken up to heaven. At the completion of the number of the 12 apostles, Peter formulates the qualifications the candidate has to meet:

So one of the men who have accompanied us during all the time that the Lord Jesus went in and out among us beginning from ( $\dot{\alpha} \rho \xi \dot{\alpha} \mu \varepsilon v o \varsigma \dot{\alpha} \pi \mathrm{o})$ the baptism of John until the day when he was taken from us ... (Ac 1:20-22)

The qualification $\dot{\alpha} \kappa \rho \imath \beta \tilde{\omega} \varsigma$ [carefully] may belong to $\gamma \rho \alpha ́ \psi \alpha 1$ [write], but it is more convenient to understand it as a qualification of the research of Luke (Fitzmyer 1981:297).

In strict sense, this qualification of the activities of the author belongs to the world behind the text. That is not the case with the word $\kappa \alpha \theta \varepsilon \xi \tilde{\eta} \varsigma$ [orderly]. This is an adverb to $\gamma \rho \alpha ́ \psi \alpha 1$ [write]. The consequence is a text that has an order. The world of the text is an orderly world. Of course, the question arises according to which order this world has been arranged. There are several proposals: a chronological, a spatial and a logical order. G. Schneider has suggested that there is an order of promise and fulfilment (Schneider 1981). It is also possible to think about an order corresponding with the laws for the story Luke wants to write. Anyway, it is clear that in the eyes of Luke, the order of the text is an orderly world.

In the prologue of his gospel, Luke speaks about the eyewitnesses who have become servants of the word. In the 
chapter about the world of the text, Sandra Schneiders speaks about the texts of the New Testament as testimony (Schneiders 1999:133-138). Of course, she mentions the prologue of the Gospel of Luke and also Luke 24:48, where Jesus says to his disciples that they have to be witnesses of all these things (Schneiders 1999:133). Historical critical approaches pay attention to the accuracy of the testimony. Sandra Schneiders puts other questions. What is the nature of testimony? If the text is a testimony, first the witness must have participated in the events in any way. The importance of the apostolic origin of the Christian tradition lies exactly in the participation in the revelatory events. A witness has to be competent to testify. 'It requires that the witness understands what happens, is trustful in relating it, and is able to articulate effectively' (Schneiders 1999: 134). A testimony is always about a matter of importance. A witness attaches his personal integrity to his testimony. But a testimony is always limited too. The reason for this is that every perception is limited. Every testimony is partial and perspectival (Schneiders 1999:135). Above this, every perception is interpretation. The expression of a testimony in language removes the testimony from the event itself. But this removal makes it possible that the testimony can be handed over. Sandra Schneiders underlines that the testimony of the New Testament is not about the pure historic events but about the revelatory meaning of those events (Schneiders 1999:137). Her opinion is congruent with the approach Joel B. Green (1997) has chosen for his commentary on the Gospel of Luke:

The approach adopted here necessarily blurs the distinction between the world of the text and the world behind the text, for it treats the text itself, this historical representation in the form of a narrative discourse, as an object of historical interest. What is more, it does so in part we believe Luke himself invited this form of inquiry and engagement. This is not to say that author of the Third Gospel was uninterested in actual events in the life of Jesus, only that the Lukan narrative is not the product of such an interest, narrowly defined. (p. 19)

It is remarkable how some elements Schneiders mentions are also present in the prologue of the Gospel of Luke. Luke indicates that there is a double transition. The events that are fulfilled among us have become word. Immediately connected with this, there is a second transition, that from the eyewitnesses to the servants of the word. Without this double transition, a testimony is not possible. The revelatory character of this testimony becomes visible in the fact that Luke wants to tell a history guided by God. We have already indicated the importance of the style according to the Septuaginta Luke uses from verse 5 in chapter 1 . We have also interpreted the passive form $\pi \varepsilon \pi \lambda \eta \rho о \varphi о \rho \eta \mu \varepsilon ́ v \omega v$ as divine passive. We are aware that the openness for this revelatory character of the testimony of the New Testament is connected with the pre-understanding of the reader and the researcher.

In the chapter about the world before the text, especially the transforming character of the reading process is discussed (Schneiders 1999:157-179). In the world before the text, the reader appropriates the text. The world of the reader and the world of the text touch each other and melt with each other. In the prologue of Luke, at least three points are important. We have already discussed the first one: the transformation of the eyewitnesses to servants of the word. This transformation is existential, because the witness identifies himself with his testimony. He guarantees his testimony with his person. The public appearance of the followers of Jesus in Acts and the boldness $(\pi \alpha \rho \rho \eta \sigma i ́ \alpha)$ of this appearance (Ac 2:29; 4:13.29.31; 28:31) show which personal and existential transformations have taken place. ' $\pi \alpha \rho \rho \eta \sigma i ́ \alpha$ is die Freiheit und Zuversicht, in der die christlichen Verkündiger trotz aller Bedrohung reden' (Schneider 1980:348-349). It is in their boldness that the transformation of the disciples of Jesus becomes visible.

A second point is the fact that Luke addresses his readers as Theophilus. We don't know who Theophilus was and what his relation was with the author of the third gospel. Many proposals have been done, but each of these proposals is just a guess. It is even not sure that Theophilus was a historic person. Some interpreters think Theophilus is a symbolic name for each reader of the book. The meaning of this name is important. This could be (1) someone who loves God or (2) someone who is loved by God. We do not want to make a decision between these two interpretations. But we want to indicate that the interpretation 'someone who loves God' corresponds with the phase of the oratio of the lectio divina: the stretching movement of a person orienting towards God. In the same way, the interpretation 'someone who is loved by God' corresponds with the contemplative phase: the movement of God meeting the longing person. Together, these two movements form the transformative understanding of the subject matter of the text.

The third point is the meaning of verse 4 . One can understand this verse in two ways: (1) so that you know about the reliability of the words you have received and (2) so that you know about the reliability of the words in which you have been instructed. For the first interpretation, interpreters refer to Acts 21:21-24, where the word $\kappa \alpha \tau \eta \chi \dot{\varepsilon} \omega$ is used in the sense of 'to inform about'. In my commentary about the Gospel of Luke, I made a choice for the second interpretation (Welzen 2011:19-20). The argument for this is Acts 18:25, where the word $\kappa \alpha \tau \chi \chi \dot{\varepsilon} \omega$ is used in the sense of 'giving instruction'. Assuming Theofilus is not the only reader aimed at, but that the Gospel of Luke is written for a Christian community, it is clear that there has been some Christian teaching. This choice for the meaning 'give instruction' has also consequences for the meaning of the word $\alpha \sigma \varphi \alpha \dot{\lambda} \varepsilon \varepsilon \alpha$ [reliability]. In our opinion, this word must not be taken in the sense of correspondence of what is told and what has happened. A kerygmatic meaning is more evident. In that case, the word $\alpha \sigma \varphi \alpha \dot{\lambda} \varepsilon \varepsilon 1 \alpha$ is a qualification of the Christian kerygma that offers a solid foundation for a Christian spiritual way. This interpretation corresponds with our other findings in reading the prologue of the Gospel of Luke. The transformation aimed at when the word of the Christian kerygma touches the world of the reader becomes visible.

In this third step of our study, we have shown that the most important elements of the hermeneutic model of Sandra 
Schneiders are present in biblical texts indicating how the Bible wants to be read. We have taken the prologue of the Gospel of Luke as an example. Our conclusion is that this text asks to be read according to a hermeneutic theory in which religious pre-understanding and spiritual transformation have been taken in account. The hermeneutic model of Sandra Schneiders meets the way of reading the biblical text asks for.

\section{Conclusion}

We come to our final conclusion. The book of Sandra Schneiders, The Revelatory Text, is innovative in relation to the common academic exegesis. It offers an integration of scholarly research and spirituality. This integration is founded in the hermeneutic of Gadamer and Ricoeur. The idea of scientific objectivity is replaced by a different criterion: that of the critical intersubjectivity. The proposals of Sandra Schneiders free the way for a new academic discipline: the discipline of biblical spirituality.

Taken in itself, biblical spirituality is not a new phenomenon. Spirituality is the specific element of the Christian way of reading from the first centuries on. Guigo II, the Carthusian, systematised this way of reading in the 12th century. Till today, lectio divina is practised. Comparison with the model of Sandra Schneiders shows the fundamental equivalents. We conclude that the model of Schneiders meets the questions the Christian tradition puts on a critical spiritual reading.

Eventually, we compared the model of Sandra Schneiders with the prologue of the Gospel of Luke. In this prologue, Luke presents his project. He elucidates how his texts want to be read. Our comparison brought into light that the model of Schneiders corresponds with the conditions in the prologue of this gospel. Both in the tradition of the lectio divina and in the prologue of the Gospel of Luke, the religious preunderstanding and the transformative understanding of the subject matter of the text are present. These elements ask for a reading different from the current practice of academic exegesis. Sandra Schneiders shows how these elements can be integrated in an academic practice. The epistemology of scholarship changes, but is not less academic. On the contrary, it is brought up to date.

\section{Acknowledgements Competing interests}

The author declares that he has no financial or personal relationships which may have inappropriately influenced him in writing this article.

\section{References}

Alexander, L., 1993, The preface of Luke's gospel. Literary conventions and socia content in Luke 1.1-4 and Acts 1.1, Cambridge University Press, Cambridge.

Baum, A.D., 2010, 'Lk 1,1-4 zwischen antiker Historiografie und Fachprosa. Zum literaturgeschichtlichen Kontext des lukanische Prologs', Zeitschrift für die neutestamentliche Wissenschaft 101, 33-54.

Bovon, F., 2006, Luke the theologien: Fifty-five years of research (1950-2005), Baylor University Press, Waco, TX.

Cadbury, H.J., 1922, 'Commentary on the preface of Luke', in J.F. Foakes Jackson \& K. Lake (eds.), The beginnings of Christianity I/2/2, pp. 489-510, Macmillan and Co, London.

Dillon, R.J., 1981, 'Previewing Luke's project from his prologue (Luke 1:1-4)', The Catholic Biblical Quarterly 43, 205-227.

Eco, U., 1983, The role of the reader. Explorations in the semiotics of texts, Hutchinson, London.

Eco, U., 1989, Lector in fabula: 'de rol van de lezer in narratieve teksten, Bert Bakker, Amsterdam.

Fitzmyer, J.A., 1981, The Gospel according to Luke (I-IX). Introduction, translation and notes, Doubleday \& Company, Garden City, NY.

Green, J.B., 1997, The gospel of Luke, W.B. Eerdmans, Grand Rapids, MI.

Guigo II, 1970, 'Epistola de vita contemplativa/Scala clautralium', in Du Cerf (ed.), Sources Chrétiennes, vol. 163, pp. 81-123, Nouvelle édition 2001, Paris.

Guigo II, 1981, The ladder of monks. A letter on the contemplative life and twelve meditations, transl. O.S.A. Edmund Colledge \& J. Walsh, Cistercian Publications, Kalamazoo, MI.

Iser, W., 1976, Der Akt des Lesens. Theorie Ästhetischer Wirkung, W. Fink, München.

Iser, W., 1979, Der implizite Leser. Kommunikationsformen des Romans von Bunyan bis Beckett, W. Fink, München.

Kurz, W.S., 1987, 'Narrative approach to Luke-Acts', Biblica 68, 195-220.

Maddox, R., 1982, The purpose of Luke-Acts, Vandenhoeck \& Ruprecht, Göttingen.

Marshall, I.H., 1978, The Gospel of Luke. A commentary on the Greek text, The Paternoster Press, Exeter.

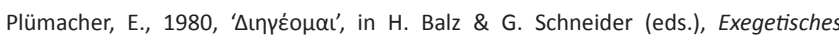
Wörterbuch zum Neuen Testament, pp. 778-780, Band I, Verlag W. Kohlhammer, Stuttgart.

Schneider, G., 1980, Die Apostelgeschichte. 1. Teil, Herder, Freiburg.

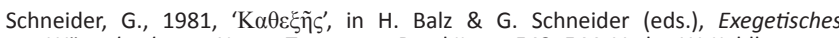
Wörterbuch zum Neuen Testament, Band II, pp. 543-544, Verlag W. Kohlhammer, Stuttgart.

Schneiders, S.M., 1999, The revelatory text. Interpreting the New Testament as sacred scripture, 2nd edn., The Liturgical Press, Collegeville, MN. [First edition in 1991].

Schneiders, S.M., 2002, 'Biblical spirituality', Interpretation: A Journal of Bible and Theology 56(2), 133-142. https://doi.org/10.1177/002096430005600202

Schneiders, S.M., 2003, Written that you may belief. Encountering Jesus in the fourth gospel, New and expanded edition, The Crossroad Publishing Company, New York.

Schneiders, S.M., 2016, 'Biblical spirituality', Interpretation: A Journal of Bible and Theology 70(4), 417-430. https://doi.org/10.1177/0020964316655108

Schröter, J., 2007, Von Jesus zum neuen Testament. Studien zur urchristluchen Theologiegeschichte und zur Entstehung des neutestamentlichen Kanons, Mohr Siebeck, Tübingen.

Van Bruggen, J., 1993, Lucas. Het evangelie als voorgeschiedenis, Kok, Kampen.

Van Unnik, W.C., 1973a, 'Éléments artistiques dans l'évangile de Luc', in F. Neirynck (ed.), L'évangile de Luc. Problèmes littéraires et théologiques. Memorial Lucien Cerfaux, pp. 129-140, University Press, Gembloux.

Van Unnik, W.C., 1973b, 'Remarks on the purpose of Luke's historical writing (Luk I 1-4)', in W.C. van Unnik (ed.), Sparsa Collecta, pp. 6-15, I. Brill, Leiden (earlier published as Opmerkingen over het doel van Lucas' geschiedwerk (Luc 1:4) Nederlands Theologisch Tijdschrift 9 (1955), no 6, 323-331).

Waaijman, K., 2002, Spirituality. Forms, foundations, methods, Peeters, Leuven.

Welzen, H., 2011, Belichting van het bijbelboek Lucas, Katholieke Bijbelstichting, Vlaamse Bijbelsstichting, 's Hertogenbosch.

Welzen, H., 2017, Biblical spirituality. Contours of a discipline, Peeters, Leuven. 